MINERALOGIA, 40, No. 1-4: 107-116 (2009)

DOI: $10.2478 / v 10002-009-0009-9$

www.Mineralogia.pl

MINERALOGICAL SOCIETY OF POLAND

Short note

\title{
Mineralogy and petrology of two ordinary chondrites and their correlation with other meteorites
}

\author{
Krzysztof OWOCKI ${ }^{1 *}$, Andrzej PILSKI ${ }^{2}$ \\ 1 Geological Institute, University of Adam Mickiewicz, ul. Maków Polnych 16, 61-686 Poznań, Poland; \\ e-mail:kowoc3@gazeta.pl \\ 2 Museum of Mikołaj Kopernik, ul. Katedralna 8, 14-530 Frombork, Poland; e-mail: aspmet@wp.pl \\ * Corresponding author
}

Received: November 11, 2009

Received in revised form: March 14, 2010

Accepted: March 15, 2010

Available online: March 30, 2010

\begin{abstract}
Two ordinary chondrites are compared and classified using transmitted and reflected light microscopy and electron microprobe analyses. Both meteorites were confiscated by the Polish Customs Service at the border with Belarus. The first meteorite (called in this paper Terespol-1) is a L/LL6 chondrite, its classification being supported by the equilibrated compositions of olivine and orthopyroxene and the presence of large recrystallized feldspars $(<150 \mu \mathrm{m})$. The specimen examined experienced weak shock metamorphism (S3) and moderate weathering (although metal in the inner part of the meteorite seems to be unaffected by oxidization). The other meteorite (called in this paper Terespol-2) is a LL6 chondrite which experienced weak shock metamorphism (S3) and is unaffected by weathering. The Terespol-2 meteorite shares its classification with the Dhofar 1401 chondrite but the lack of data prevents further correlation. Both meteorites have been correlated with known findings from the Meteoritical Bulletin database and an attempt is made to identify their place of origin (fall event). Results indicate that Terespol- 1 is most closely related to the Dhofar 1316 chondrite and we suggest that both meteorites at least came from the same parent body.
\end{abstract}

Key-words: ordinary chondrite, type 6 chondrite, shock metamorphism, Dhofar

\section{Introduction}

In 2005, the Polish Customs Service confiscated two large samples of ordinary chondrites at the border crossing in Terespol. The loss of important information about the exact date and location of the find is an unfortunate consequence of the illegal trade of meteorites. The aim of 
this work was to examine and classify the meteoritic material. We have also attempted to determine the original location of these findings by correlating our research results with the descriptions of meteorites classified in the Meteoritical Bulletin database.

\section{Material and methods}

\subsection{Physical description}

The first meteorite (Terespol-1) weighs 467.73 grams. It has a very thin, brown fission crust and is moderately weathered with a rusty-coloured interior. However, some fine-grained nickel-iron grains are unaffected by weathering. Several light grey shock veins of coarse-grained, recrystallized silicate material are visible. In thin section, the transparent silicate matrix of the meteorite is recrystallized and chondrules have poorly defined boundaries in the cross-polarized light (Fig. 1). Although porphyritic olivine and olivine-pyroxene chondrules dominate $(\sim 0.7 \mathrm{~mm}$ in diameter), there are also two large, recrystallized, radial-pyroxene chondrules $(4.5 \mathrm{~mm}$ and $2.5 \mathrm{~mm}$ in diameter). Metal and sulphides are present as fine-grained sub-angular inclusions scattered in the transparent silicate matrix (Fig. 2).

The second meteorite (Terespol-2) weighs 486.91 grams. It has a characteristic dark brown fission crust covered with light pink calcretes and does not show weathering. The interior of the meteorite is dark grey to black and medium- to fine-grained with fine-grained, regular or amoeboid-shaped nickel-iron inclusions. In thin section, the meteorite is dark grey inside with

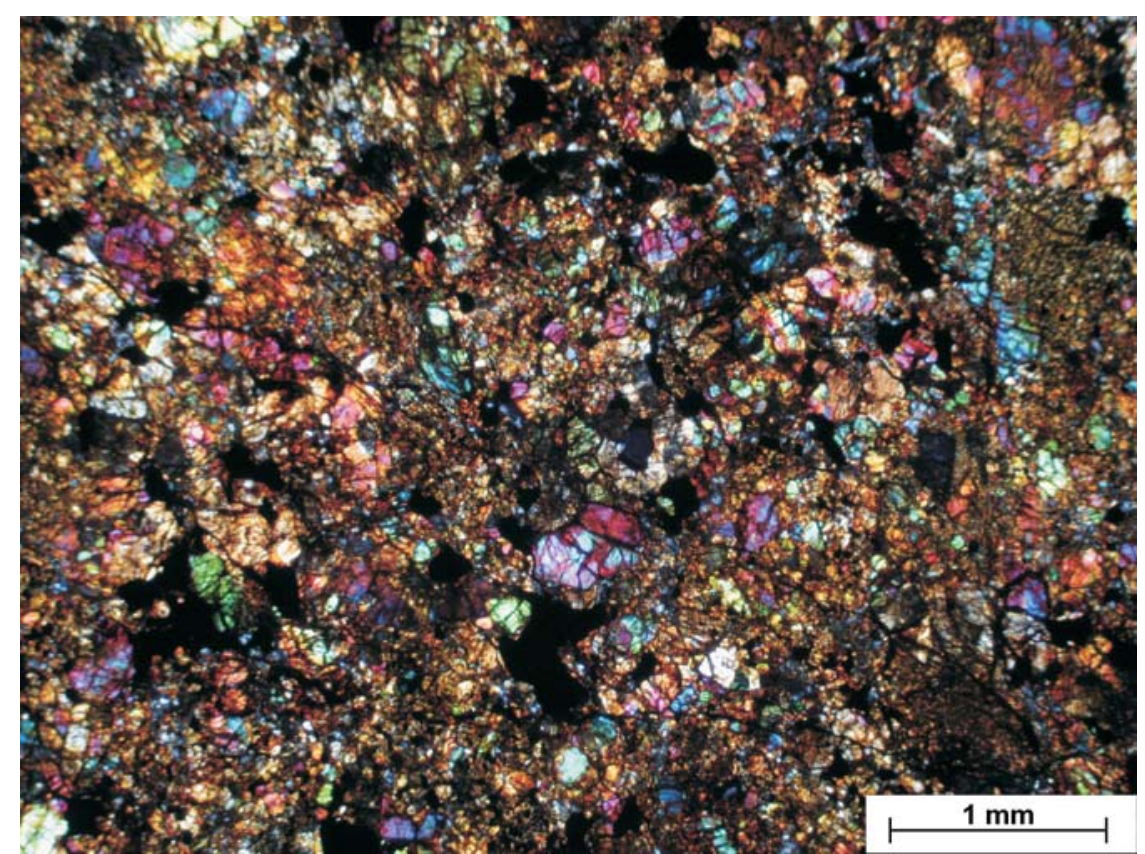

Fig. 1. Structure and texture of Terespol-1 ordinary chondrite (transmitted light, XP) 


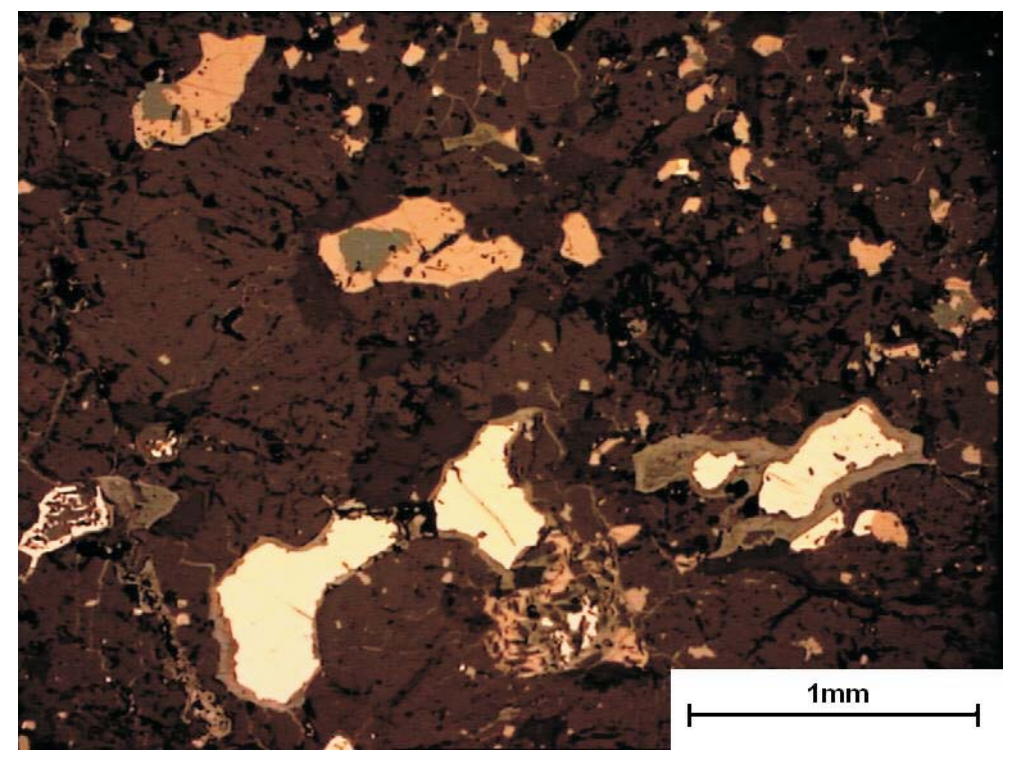

Fig. 2. Kamacite (white), troilite (pinkish) in Terespol-1 ordinary chondrite (reflected light, PPL)

small light metal inclusions and its chondrules are recrystallized with poorly defined boundaries. The chondrules are predominantly of the porphyritic olivine and porphyritic olivine-pyroxene types. There are also two large ( 3 and $4 \mathrm{~mm}$ across), recrystallized, radial-pyroxene chondrules and one barred-olivine chondrule. Metal and sulphides are present as fine-grained, disseminated inclusions surrounded by a transparent recrystallized silicate matrix.

Both examined specimens are now a part of the meteoritical collection of the Geological Institute, University of Adam Mickiewicz in Poznań.

\subsection{Analytical methods}

Two slices (one of each meteorite) were cut and polished. Thin sections were prepared and used for petrographic examinations (transmitted and reflected light microscopy) and electron microprobe analyses. Backscattered electron images and electron microprobe data were obtained using a Cameca SX-100 electron microprobe at the Electron Microprobe Laboratory of the Inter-Institute Analytical Complex for Minerals and Synthetic Substances, University of Warsaw. The instrument was operated at an acceleration voltage of $15 \mathrm{kV}$ and a beam current of $20 \mathrm{nA}$. Natural standard reference minerals were used.

\section{Results}

\subsection{Terespol-1 meteorite}

The chondrules and coarse-grained crystalline matrix are composed predominantly of olivine with lesser amounts of orthopyroxene. The olivine has a mean composition of Fo $74.9 / \mathrm{Fa}$ 
$25.1 \mathrm{~mol} \%$ with low contents of $\mathrm{CaO}(\sim 0.05 \mathrm{wt} \%), \mathrm{TiO}_{2}, \mathrm{Cr}_{2} \mathrm{O}_{3}$ and $\mathrm{Al}_{2} \mathrm{O}_{3}(<0.05 \mathrm{wt} \%)$. The fayalite percent mean deviation (PMD - standard deviation expressed as a percentage of the mean) of the olivine is below $<1 \%$. Ca-poor pyroxenes have a mean composition of Wo 1.64/En 77.36 / Fs 20.94 mol\% with the ferrosillite percent mean deviation below $<0.5 \%$. $\mathrm{The} \mathrm{Fe} /(\mathrm{Fe}+\mathrm{Mg})$ ratio is higher in the olivine (mean 25.87) than in the Ca-poor pyroxene (mean 20.94). A Ni-poor ( 4 $\mathrm{wt} \%$ ) kamacite is often present as amoeboidal or polygonal

TABLE 1

Average chemical compositions of major minerals in the Terespol-1 ordinary chondrite

\begin{tabular}{|c|c|c|c|}
\hline Component (wt\%) & Olivine $\mathrm{n}=28$ & Orthopyroxene $\mathrm{n}=18$ & Feldspar $\mathrm{n}=6$ \\
\hline $\mathrm{SiO}_{2}$ & 37.75 & 55.11 & 63.39 \\
\hline $\mathrm{TiO}_{2}$ & 0.02 & 0.17 & b.d.1 \\
\hline $\mathrm{Al}_{2} \mathrm{O}_{3}$ & 0.01 & 0.13 & 20.77 \\
\hline $\mathrm{Cr}_{2} \mathrm{O}_{3}$ & 0.01 & 0.12 & b.d.1 \\
\hline $\mathrm{MgO}$ & 38.22 & 28.51 & b.d.1 \\
\hline $\mathrm{CaO}$ & 0.05 & 0.84 & 2.07 \\
\hline $\mathrm{MnO}$ & 0.46 & 0.47 & b.d.1 \\
\hline $\mathrm{FeO}$ & 23.3 & 13.31 & 3.96 \\
\hline $\mathrm{NiO}$ & 0.07 & 0.07 & b.d.1 \\
\hline $\mathrm{Na}_{2} \mathrm{O}$ & 0.03 & 0.07 & 9.08 \\
\hline $\mathrm{K}_{2} \mathrm{O}$ & b.d.1 & b.d.1 & 0.73 \\
\hline Total & 99.92 & 98.80 & 100.00 \\
\hline $\mathrm{Fe} /(\mathrm{Fe}+\mathrm{Mg})$ & 25.86 & 21.31 & - \\
\hline PMD & 0.74 & 0.32 & - \\
\hline Cation formula based on & 4 oxygens & 6 oxygens & 8 oxygens \\
\hline $\mathrm{Si}$ & 0.99 & 1.98 & 2.9 \\
\hline $\mathrm{Ti}$ & b.d.l & b.d.l & b.d.l \\
\hline $\mathrm{Al}$ & b.d.1 & 0.01 & 1.1 \\
\hline $\mathrm{Cr}$ & b.d.1 & b.d.1 & b.d.1 \\
\hline $\mathrm{Mg}$ & 1.5 & 1.53 & b.d.1 \\
\hline $\mathrm{Ca}$ & b.d.1 & 0.03 & 0.12 \\
\hline $\mathrm{Mn}$ & 0.01 & 0.01 & b.d.1 \\
\hline $\mathrm{Fe}$ & 0.51 & 0.4 & 0.01 \\
\hline $\mathrm{Ni}$ & b.d.1 & b.d.1 & b.d.1 \\
\hline $\mathrm{Na}$ & b.d.l & b.d.1 & 0.8 \\
\hline $\mathrm{K}$ & b.d.1 & b.d.1 & 0.04 \\
\hline Total & 3.01 & 3.96 & 4.97 \\
\hline
\end{tabular}

Abbreviations: b.d.l. - below detection limit; PMD - percent mean deviation. 


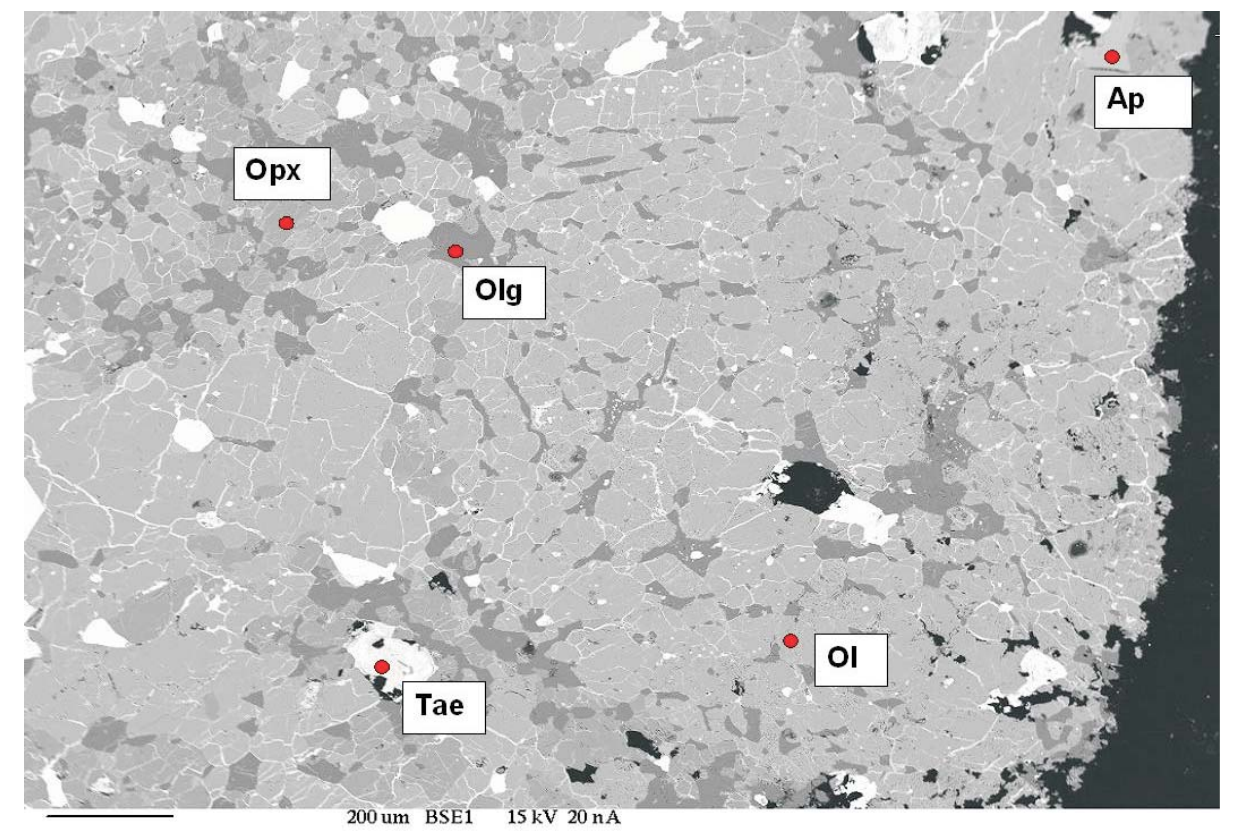

Fig. 3. Back-scattered electron micrograph of Terespol-1 ordinary chondrite. Abbreviations: Ap - Apatite, Ol - olivine, Olg - oligoclase feldspar, Opx - orthopyroxene,

Tae - taenite (scale bar - $200 \mu \mathrm{m})$

inclusions, often with taenite ( $\mathrm{Ni} \sim 26-35 \mathrm{wt} \%$ ) outer rims. Fine-grained polygonal metal-sulphide inclusions are very rare. Close to the fission crust, the metallic grains reveal minor signs of weathering.

Common accessory phases are phosphates, both apatite- $(\mathrm{CaCl})$ and merrillite $(<3.033 \mathrm{wt} \%$ $\left.\mathrm{Na}_{2} \mathrm{O}\right)$ with grains $<100 \mu \mathrm{m}$. Feldspars are a common minor, coarse-grained $(<150 \mu \mathrm{m})$ phase with a mean composition of Ab 84.24 / Or 4.41/An 10.67 mol\% (Table 1; Fig. 3).

Undulose extinction is very common in the olivine. Some planar deformation fractures are present in both, olivine and the Ca-poor pyroxene. Larger fractures and some irregular cracks are filled with Fe-Ni metal alloy. Several shock veins are filled with a once molten, recrystallized silicate material.

\subsection{Terespol-2 meteorite}

This meteorite has similar petrology to the Terespol-1 meteorite. The chondrules and coarse-grained crystalline matrix are composed predominantly of olivine and orthopyroxene. Olivine has the mean composition of Fo $73.77 / \mathrm{Fa} 25.80 \mathrm{~mol} \%$ with the fayalite content percent mean deviation below $<1 \%$. The contents of $\mathrm{CaO}, \mathrm{Al}_{2} \mathrm{O}_{3}, \mathrm{Cr}_{2} \mathrm{O}_{3}$ in the olivine are lower than $<0.1 \mathrm{wt} \%$ (Table 2). Ca-poor pyroxenes have a mean composition of Wo $1.82 /$ En $76.09 / \mathrm{Fs} 22.08 \mathrm{~mol} \%$ and have the ferrosillite percent mean deviation below $<0.5 \%$. The $\mathrm{Fe} /(\mathrm{Fe}+\mathrm{Mg})$ ratio in the olivine (mean 26.28) is higher than in the Ca-poor pyroxene (mean 22.49). 
Average chemical compositions of major minerals in the Terespol-2 ordinary chondrite

\begin{tabular}{|c|c|c|c|}
\hline Component (wt\%) & Olivine $\mathrm{n}=6$ & Orthopyroxene $n=6$ & Feldspar $n=2$ \\
\hline $\mathrm{SiO}_{2}$ & 38.54 & 55.54 & 67.99 \\
\hline $\mathrm{TiO}_{2}$ & 0.01 & 0.17 & b.d.l. \\
\hline $\mathrm{Al}_{2} \mathrm{O}_{3}$ & b.d.l. & 0.12 & 22.27 \\
\hline $\mathrm{Cr}_{2} \mathrm{O}_{3}$ & 0.01 & 0.12 & b.d.l. \\
\hline $\mathrm{MgO}$ & 37.4 & 27.94 & b.d.1. \\
\hline $\mathrm{CaO}$ & 0.05 & 0.99 & 2.35 \\
\hline $\mathrm{MnO}$ & 0.45 & 0.42 & b.d.1. \\
\hline $\mathrm{FeO}$ & 23.31 & 14 & 0.49 \\
\hline $\mathrm{NiO}$ & 0.03 & 0.25 & b.d.l. \\
\hline $\mathrm{Na}_{2} \mathrm{O}$ & 0.01 & 0.03 & 6.61 \\
\hline $\mathrm{K}_{2} \mathrm{O}$ & b.d.1. & 0.01 & 0.53 \\
\hline Total & 99.81 & 99.59 & 100.24 \\
\hline $\mathrm{Fe} /(\mathrm{Fe}+\mathrm{Mg})$ & 26.29 & 22.46 & - \\
\hline PMD & 0.68 & 0.31 & - \\
\hline Cation formula based on & 4 oxygens & 6 oxygens & 8 oxygens \\
\hline $\mathrm{Si}$ & 1.01 & 2 & 2.96 \\
\hline $\mathrm{Ti}$ & b.d.l. & 0.01 & b.d.l. \\
\hline $\mathrm{Al}$ & b.d.l. & 0.01 & 1.14 \\
\hline $\mathrm{Cr}$ & b.d.l. & b.d.l. & b.d.l. \\
\hline $\mathrm{Mg}$ & 1.46 & 1.5 & b.d.l. \\
\hline $\mathrm{Ca}$ & b.d.l. & 0.04 & 0.12 \\
\hline $\mathrm{Mn}$ & 0.01 & 0.01 & b.d.l. \\
\hline $\mathrm{Fe}$ & 0.51 & 0.42 & 0.01 \\
\hline $\mathrm{Ni}$ & b.d.l. & b.d.l. & b.d.l. \\
\hline $\mathrm{Na}$ & b.d.l. & b.d.l. & 0.78 \\
\hline $\mathrm{K}$ & b.d.l. & b.d.1. & 0.04 \\
\hline Total & 2.99 & 3.99 & 5.05 \\
\hline
\end{tabular}

Abbreviations: b.d.1. - below detection limit; PMD - percent mean deviation.

Feldspars are a common minor coarse-grained phase $(<150 \mu \mathrm{m}$; Fig. 4) with the mean composition of Ab 79.97/ Or 4.29/ An 15.74 mol\%.

Metal and sulphide are common and occur as large, amoeboidal or polygonal inclusions unaffected by weathering. A polygonal (shock effect) troilite is Ni-rich $(<5 \mathrm{wt} \%)$.

Undulose extinction is very common in the olivine. Planar deformation fractures are pervasive in both, olivine and Ca-poor pyroxene. Larger fractures and some irregular cracks 


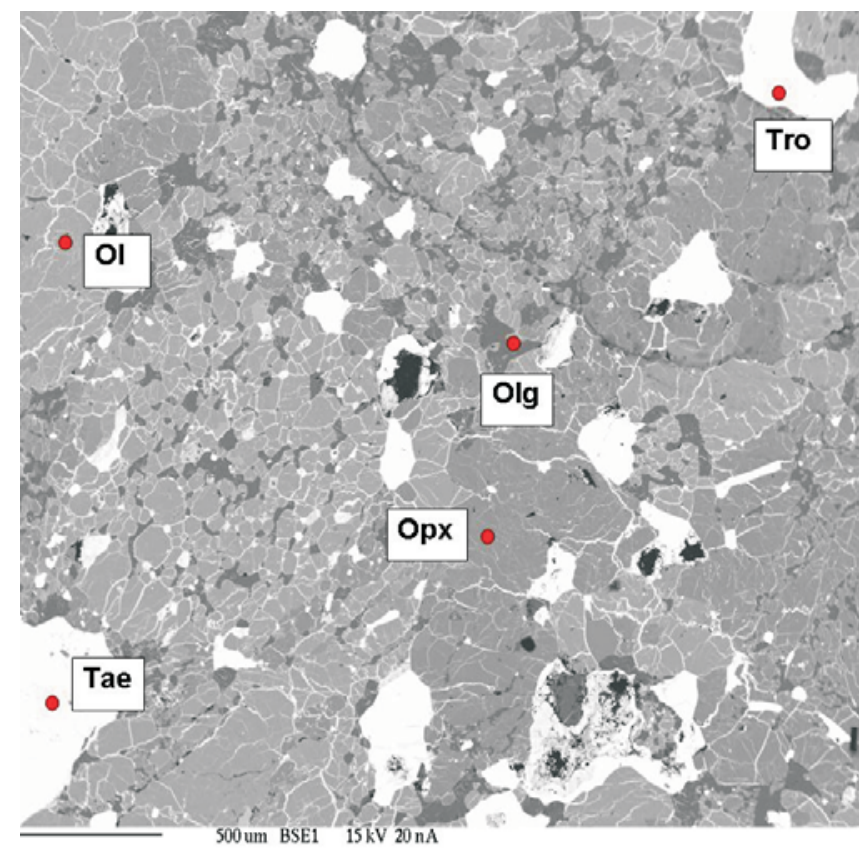

Fig. 4. Back-scattered electron micrograph of Terespol-2 ordinary chondrite. Abbreviations: $\mathrm{Ol}$ - olivine, $\mathrm{Olg}$ - oligoclase feldspar, Opx - orthopyroxene, Tae - taenite, Tro - troilite (scale bar $-500 \mu \mathrm{m})$

are filled with metallic grains. A single shock vein is filled with a dark, once molten, silicate material.

\section{Interpretation}

\subsection{Terespol-1 meteorite}

The olivine composition is well equilibrated (low fayalite PMD) and falls within the range of the L-chondrites. The orthopyroxene composition is highly equilibrated (very low ferrosillite PMD) and shows that the meteorite belongs to the LL-group. The highly equilibrated mineral composition, coarse-grained crystalline matrix and poorly defined chondrule boundaries suggest that this meteorite belongs to type 6 meteorites in the classification of Van Schmus and Wood (1967). This has been confirmed using the Lindley (1983) pyroxene thermometer, with a Ca-poor pyroxene equilibration temperature estimated to be no lower than $750^{\circ} \mathrm{C}$.

The undulose extinction in olivine, the shock veins and planar deformation fractures in the silicates indicate that the meteorite was weakly shocked after metamorphism. According to the classification of Stöffler and his co-workers (Stöffler et al. 1991), the shock facies is estimated to be S3, i.e. weakly shocked. The maximum shock temperature measured with the $\mathrm{Ca} /(\mathrm{Ca}+\mathrm{Fe}+\mathrm{Mg})$ pyroxene thermometer (Putirka 2005) is estimated to be around $1075^{\circ} \mathrm{C}$ 


\subsection{Terespol-2 meteorite}

The olivine composition is within the range of the LL-chondrites and the orthopyroxene composition shows that the meteorite belongs to the LL-group. The highly equilibrated mineral composition (PMD $<1 \%$ ), coarse-grained crystalline matrix and poorly defined chondrule boundaries suggest that this meteorite is a type 6 meteorite in the classification of Van Schmus and Wood (1967). The Ca-poor pyroxene equilibration temperature, estimated with the Lindsley (1983) pyroxene thermometer, is not lower than $800^{\circ} \mathrm{C}$.

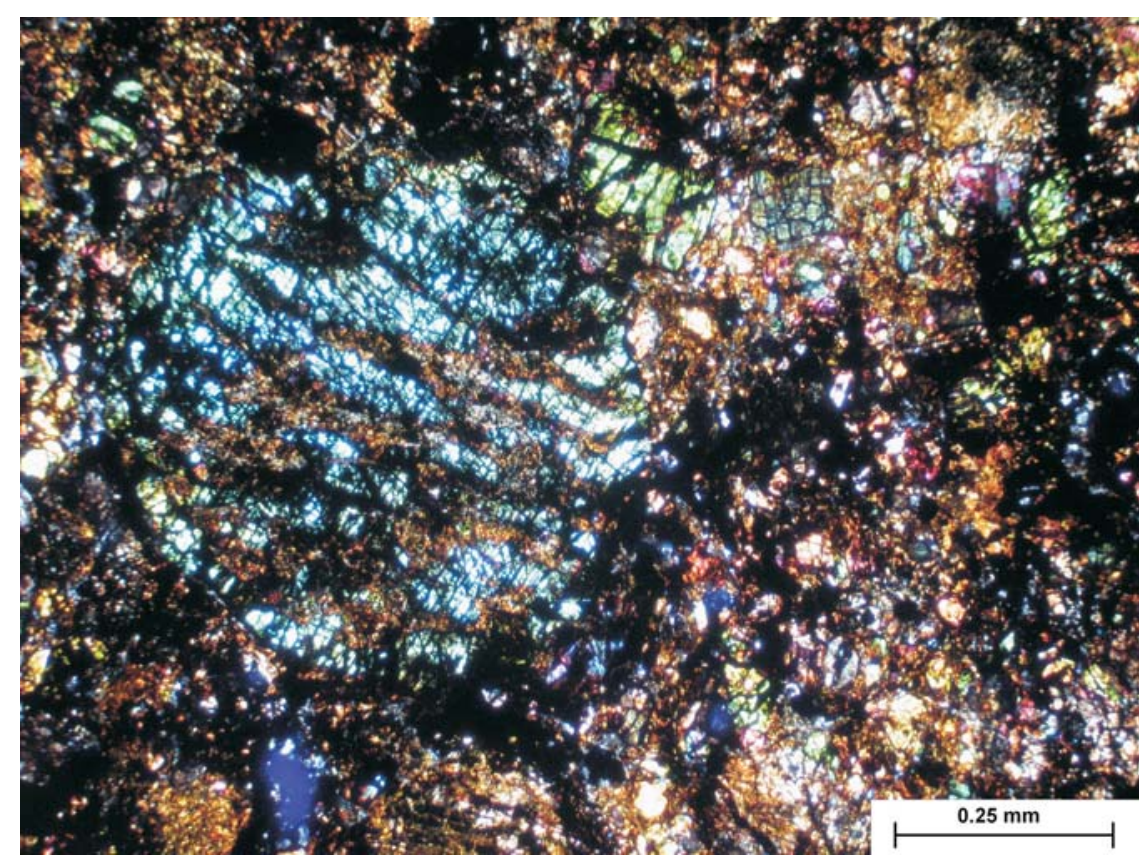

Fig. 5. Barred olivine chondrule in Terespol-2 ordinary chondrite. Note planar deformation fractures (transmitted light, XP)

The presence of the undulose extinction in the olivine, pervasive planar deformation fractures (Fig. 5) and the shock vein indicate that the meteorite has been weakly shocked after metamorphism. According to the classification of Stöffler et al. (1991), the shock facies is estimated to be S3, i.e. weakly shocked. The maximum shock temperature measured with the $\mathrm{Ca} /(\mathrm{Ca}+\mathrm{Fe}+\mathrm{Mg}$ ) pyroxene thermometer (Putirka 2005) is estimated to be around $1100-1150^{\circ} \mathrm{C}$.

\subsection{Probable location of the findings}

The results were compared with the petrological and chemical data available from the Meteoritical Bulletin database. The petrology, mineral composition and shock facies of the Terespol-1 meteorite most closely match those of Dhofar 1316, the L/LL6 S3 W4 chondrite found in Oman at location $19^{\circ} 02.7^{\prime} \mathrm{N} 54^{\circ} 23.6^{\prime} \mathrm{E}$ (Connolly et al. 2007). This meteorite slightly 
differs from Terespol-1 in its chemical composition (Fa $\sim 26.4 / \mathrm{Fs} \sim 22.5 / \mathrm{Wo} \sim 1.5 \mathrm{~mol} \%$ ). We suggest that both meteorites come from the same parent body and perhaps from the same fall event.

The petrology and classification of the Terespol-2 meteorite most closely match those of the Dhofar 1401 meteorite $\left(19^{\circ} 11.5^{\prime}\right.$ N 5439.3' E; LL6 W1-2; Grossman, Zipfel 2001). However, as its mineral composition has not been published, full comparison is impossible.

\section{Conclusions}

The two meteorites examined are weakly shocked type 6 ordinary chondrites. Terespol- 1 has a composition between that of L and LL chondrites and is closely related to Dhofar 1316.L/LL chondrite found in Oman. Terespol-2 is a LL chondrite and is probably related to the Dhofar 1401 chondrite from Oman. Calcretes covering the meteorites, and the moderate or no weathering, suggest that they fell on a harsh, dry desert like that in the Dhofar region.

Acknowledgements. The authors would like to acknowledge two anonymous reviewers for their valuable comments and discussion that helped improve the paper.

\section{References}

Connolly C.H., Zipfel J., Folco L., Smith C., Jones R.H., Benedix G., Righter K., Yamaguchi A., Aoudjehane H.Ch., Grossman J.N. (2007). The Meteoritical Bulletin No. 91, Meteoritics \& Planetary Science, 42, 413-466. Retrieved from the Meteoritical Bulletin Database http://tin.er.usgs.gov/meteor/docs/mb92.pdf

Grossman J.N., \& Zipfel J. (2001). The Meteoritical Bulletin No. 85, Meteoritics \& Planetary Science, 36, $293-322$. Retrieved from the Meteoritical Bulletin Database http://tin.er.usgs.gov/meteor/docs/mb85.pdf

Lindsley D.H. (1983). Pyroxene thermometry. American Mineralogist, 68, 477-493.

Putirka K.D. (2005). Mantle potential temperatures at Hawaii, Iceland and mid-ocean ridges systems, as inferred from olivine phenocrysts: evidence for thermally driven mantle plumes. Geochemical and Geological Geosystems, 6 , 1-14. DOI: $10.1029 / 2005$ GC000915

Stöffler D., Keil K., Scott E.R.D. (1991). Shock metamorphism of ordinary chondrites. Geochimica et Cosmochimica Acta, 55, 3845-3867. DOI:10.1016/S0016-7037(99)00149-0

Van Schmus W.R., \& Wood J.A. (1967). A chemical-petrologic classification for the chondritic meteorites. Geochimica et Cosmochimica Acta, 31, 47-765. DOI: 10.1016/S0016-7037(67)80030-9 